Jurnal PG-PAUD Trunojoyo : Jurnal Pendidikan dan Pembelajaran Anak Usia Dini, Volume 6, Nomor 2, Oktober 2019, hal 101-108, ISSN : 2528-3553 (online), ISSN: 2407-4454 (print)

\title{
PENINGKATAN KEMAMPUAN BERHITUNG DENGAN MENGGUNAKAN METODE FINGERMATHIC PADA ANAK USIA DINI
}

\author{
Norma Diana Fitri \\ Indaria Tri Hariani \\ Program Studi Pendidikan Guru Pendidikan Anak Usia Dini STKIP Bina Insan Mandiri \\ Email: normadiana@ stkipbim.ac.id, indariatrihariani@stkipbim.ac.id
}

Received (Bulan Agustus 2019), Accepted (Bulan September 2019), Published (Bulan Oktober 2019)

\begin{abstract}
The learning process in kindergarten is still very conventional in nature. This is shown in teaching and learning activities in kindergarten Tunas Asri Benowo Surabaya, in introducing the number of teachers still using the lecture method, and memorizing. To count numbers children still write in the book given by their teacher. The research is currently doing is to improve numeracy skills in children aged 5-6 years with interesting activities for children by providing learning methods needed for children. This research method uses Classroom Action Research. The research subjects were 13 students consisting of 7 boys and 6 girls. The data analysis technique used is descriptive analysis technique. The results of this study indicate that the fingermathic method can improve numeracy skills. In the pre cycle of $69.23 \%$ which is in the criteria of Not Developing, in the first cycle the action taken through the fingermathic method increased to $53.85 \%$ in the criteria of Developing in Accordance with Expectations, and increased in the second cycle to $84.62 \%$ on criteria according to Expectations and Very Good Developments. Based on the results of this study, it shows that an increase in numeracy skills of children aged 5-6 years with fingermathic methods.
\end{abstract}

Keywords: Improvement, Counting Ability, Fingermathic Method

\begin{abstract}
Abstrak: Proses pembelajaran di Taman Kanak-Kanak masih sangat bersifat konvensional. Hal ini ditunjukkan pada kegiatan belajar mengajar di TK Tunas Asri Benowo Surabaya, dalam mengenalkan angka guru masih menggunakan metode ceramah, dan hafalan. Untuk menghitung bilangan anak-anak masih menulis pada buku yang diberikan oleh gurunya. Penelitian ini adalah untuk meningkatkan kemampuan berhitung pada anak usia 56 tahun dengan kegiatan yang menarik bagi anak yaitu dengan memberikan metode pembelajaran yang dibutuhkan untuk anak. Metode Penelitian ini menggunakan Penelitian Tindakan Kelas. Subyek penelitian berjumlah 13 anak yang terdiri dari 7 anak laki-laki dan 6 anak perempuan. Teknik analisis data yang digunakan yaitu teknik analisis deskriptif. Hasil penelitian ini menunjukkan bahwa metode fingermathic dapat meningkatkan kemampuan berhitung. Pada pra siklus sebesar 69,23\% yang berada pada kriteria Belum Berkembang (BB), pada siklus I dilakukan tindakan melalui metode fingermathic meningkat menjadi 53,85\% pada kriteria Berkembang Sesuai Harapan (BSH), dan meningkat pada siklus II menjadi 84,62\% pada kriteria Berkembang Sesuai harapan (BSH) dan Berkembang Sangat Baik (BSB). Berdasarkan hasil penelitian ini, menunjukkan bahwa terjadi peningkatan kemampuan berhitung anak usia 5-6 tahun dengan metode fingermathic.
\end{abstract}

Kata Kunci : Peningkatan, Kemampuan Berhitung, Metode Fingermathic

\section{PENDAHULUAN}

Anak usia dini atau "early childhood" menurut National Assocition for the Education Young Children (NAEYC) merupakan anak yang berada pada usia nol sampai dengan delapan tahun. Pada masa tersebut merupakan proses pertumbuhan dan perkembangan dalam berbagai aspek dalam rentang kehidupan manusia. Proses pembelajaran terhadap anak harus memerhatikan karekteristik yang dimiliki dalam tahap perkembangan anak (Suyanto, 2013:1).

Pendidikan Anak Usia Dini (PAUD) adalah pendidikan yang diberikan bagi anak usia dini (0-6 tahun) yang dilakukan melalui pemberian berbagai rangsangan untuk membantu pertumbuhan dan perkembangan baik jasmani maupun rohani agar memiliki kesiapan untuk memasuki jenjang pendidikan berikutnya. Melalui PAUD, diharapkan anak dapat mengembangkan seluruh potensi yang dimilikinya yang meliputi pengembangan moral dan nilai-nilai agama, fisik, sosial, emosional, bahasa, seni, menguasai sejumlah pengetahuan dan keterampilan sesuai dengan perkembangan, serta memiliki motivasi dan sikap, belajar untuk berkreasi (Susanto,2017:16). 
102 Jurnal PG-PAUD Trunojoyo : Jurnal Pendidikan dan Pembelajaran Anak Usia Dini, Volume 6, Nomor 2, Oktober 2019, hal 101 - 108, ISSN : 2528-3553 (online), ISSN: 2407-4454 (print)

Kognitif berasal dari kata cognition yang berarti pengertian atau mengerti. Dalam perkembangan selanjutnya, istilah kognitif berkembang meliputi setiap perilaku mental yang berhubungan dengan masalah pemahaman, memperhatikan, memberikan, menyangka, pertimbangan, pengolahan informasi, pemecahan masalah, kesengajaan, pertimbangan, membayangkan, memperkirakan, berpikir, dan keyakinan (Indrijati, 2015:44).

Perkembangan kognitif anak terdiri dari tiga tahapan. Pertama, tahap sensorimotor, yaitu anak sejak lahir hingga usia sekitar satu dan dua tahun memahami objek disekitarnya melalui sensori dan aktivitas motor atau gerakannya. Kedua, tahap praoperasional, yaitu dimana proses berpikir anak berpusat pada penguasaan simbol-simbol yang mampu mengungkapkan pengalaman masa lalu. Kesulitan yang dialami anak berkaitan dengan perceptual centration, irreversibility, dan egosentrism. Ketiga, tahap operasional konkret dimana anak mulai mampu mengatasi masalah yang berkaitan dengan conservation, perceptual centration, dan egocentrism, namun masih bersifat konkret, yang belum yang bersifat abstrak. Hal yang bersifat abstrak baru dicapai pada tahap berikutnya, yaitu tahap formal operasional (Piaget dalam Susanto, 2017:11).

Kemampuan berhitung merupakan bagian keterampilan yang diperlukan dalam kehidupan sehari-hari. Berhitung adalah ilmu pasti yang tidak bisa diterka ataupun ditebak, selain itu berhitung merupakan salah satu ilmu yang dapat digunakan dalam kehidupan seharihari, mulai dari anak-anak, orang dewasa, sampai orang tua (Kuraesin, 2013: 1).

Menurut Piaget dalam Suyanto (2005), tujuan pembelajaran berhitung anak usia dini sebagai logico-mathematical learning atau belajar berpikir logis dan matematis dengan cara yang menyenangkan dan tidak rumit. Sehingga bukan agar anak dapat menghitung sampai seratus atau seribu, tetapi memahami bahasa matematis dan penggunaannya untuk berpikir. Tujuan pembelajaran berhitung anak usia dini, yaitu untuk melatih anak berpikir logis dan sistematis sejak dini dan mengenalkan dasar-dasar pembelajaran berhitung sehinga pada saatnya nanti anak akan lebih siap mengikuti pembelajaran berhitung pada jenjang selanjutnya yang lebih kompleks.
Berhitung merupakan dasar dari beberapa ilmu yang digunakan dalam kehidupan seharihari seperti, penambahan, pengurangan, pembagian, ataupun perkalian. Untuk anak usia dini dapat menambah dan mengurangi serta membandingkan sudah sangat baik setelah anak memahami bilangan dan angka (Suyanto, 2005: 73). Pendekatan ini dilaksanakan melalui bermain, melibatkan anak dalam berbagai kegiatan baik kegiatan yang bersifat individual, kelompok kecil, maupun kelompok besar. Selain itu, motivasi dan minat yang sesuai dengan anak perlu diperhatikan agar pembelajaran dapat diterima anak dengan baik.

Terkadang anak mengalami kesulitan dalam belajar berhitung. Kesulitan anak dalam berhitung seperti menyebutkan angka 1 sampai 20, mengurutkan angka 1 sampai 20, penjumlahan, pengurangan dapat disebabkan oleh berbagai hal antara lain kejenuhan, keterbatasan daya ingat, dan lemahnya konsentrasi berhitung termasuk kegiatan yang menuntut latihan terus menerus, konsentrasi, dan ketekunan sehingga kerap terkesan membosankan bagi anak karena yang dilatih hanya dengan lembar kerja anak dan guru menjelaskan di papan tulis. Selain itu, tidak semua anak memiliki kemampuan daya ingat dan kemampuan konsentrasi yang memadai sehingga berhitung akan terasa sebagai beban yang berat bagi anak. Memahami tentang pentingnya kemampuan berhitung sejak dini, perlunya penggunaan cara dan strategi yang tepat dalam pembelajaran berhitung pada anak usia dini (Kusnaeni, 2005: 5).

Berdasarkan observasi awal, kemampuan berhitung anak usia TK B (5-6 tahun) yaitu menyebutkan lambang bilangan 1-10, menggunakan lambang bilangan untuk menghitung, mencocokkan bilangan dengan lambang bilangan (Permendikbud No. 137:2014). Menurut pengamatan peneliti, kemampuan berhitung di TK Tunas Asri Benowo Surabaya hanya 28\% dari 13 siswa atau hanya sekitar 3 siswa saja yang memenuhi standar tingkat pencapaian perkembangan anak menurut Permendikbud no. 137. Sedangkan $72 \%$ sisanya atau sekitar 10 siswa belum menguasai kemampuan berhitung. Sehingga masih memerlukan bimbingan guru.

Berdasarkan dari hasil observasi yang dilakukan di TK Tunas Asri Benowo Surabaya peneliti mencoba menggunakan metode yang 
Jurnal PG-PAUD Trunojoyo : Jurnal Pendidikan dan Pembelajaran Anak Usia Dini, Volume 6, Nomor 2, Oktober 2019, hal $101-108$, ISSN : 2528-3553 (online), ISSN: 2407-4454 (print)

bisa digunakan dalam pembelajaran berhitung, dengan mempertimbangkan berdasarkan kebutuhan anak dan sesuai dengan usia anak. Peneliti menggunakan metode fingermathic, hal ini dilakukan untuk menarik perhatian anak agar anak tidak bosan dengan cara yang menyenangkan. Metode Fingermathic ini mengajak anak untuk ikut berperan aktif dalam melaksanakan pembelajaran, karena di dalam metode fingermathic mempunyai cara yang dapat menciptakan suasana belajar menjadi efisien dan menyenangkan.

Kegiatan pembelajaran dengan menggunakan metode fingermathic yang menarik dapat memberikan stimulasi pada anak untuk meningkatkan kemampuan berhitung. Penelitian mengenai penggunaan metode fingermathic yang dapat meningkatkan kemampuan berhitung anak penting untuk dikaji. Hal ini dimaksudkan agar guru mendapatkan pengetahuan baru dalam menggunakan metode yang efektif untuk meningkatkan kemampuan berhitung anak. Oleh karena itu penelitian ini mengambil judul "Peningkatan Kemampuan Berhitung Melaui Metode Fingermathic Pada Anak Usia Dini".

\section{METODE}

Penelitian ini merupakan Penelitian Tindakan Kelas (PTK) atau Classroom Action Research (CAR) menyatakan bahwa penelitian tindakan kelas merupakan suatu bentuk penelitian refleksif diri kolektif yang dilakukan oleh para guru dalam sebuah situasi untuk meningkatkan penalaran dan keadilan praktik pendidikan dan praktik sosial, serta pemahaman terhadap praktik dan terhadap situasi di tempat praktik yang dilakukan (Arikunto, 2010).

Dalam penelitian ini, peneliti ingin mengungkapkan permasalahan tentang peningkatan kemampuan berhitung dengan menggunakan metode fingermathic di TK Tunas Asri Benowo Surabaya. Penelitian ini adalah bentuk penelitian yang dilakukan oleh guru di dalam kelasnya secara kolaborasi dalam proses pembelajaran guna memperbaiki keadaan agar lebih baik lagi.

Arikunto (2010: 3) Penelitian Tindakan Kelas merupakan suatu pencermatan terhadap kegiatan belajar berupa sebuah tindakan, yang sengaja dimunculkan dan terjadi dalam sebuah kelas secara bersama.
Dari pengertian diatas dapat diambil kesimpulan penelitian tindakan kelas adalah penelitian yang dilakukan seorang guru didalam kelasnya sendiri, yang dimaksudkan untuk mengumpulkan data dari satu perlakuan yang sudah dilakukan oleh guru sampai masalah itu dapat terpecahkan yang mana penelitian tindakan kelas itu sendiri bertujuan untuk memperbaiki mutu pembelajaran dikelasnya.

Berdasarkan gambar 1 alur pelaksanaan tindakan yang dilakukan oleh peneliti adalah sebagai berikut tahap perencanaan, pelaksanaan tindakan, observasi atau pengamatan, dan refleksi terhadap tindakan yang telah dilakukan.

\section{Siklus I}

a. Perencanaan

Perencanaan merupakan penjelasan tentang apa, mengapa, kapan, dimana, oleh siapa, dan bagaimana tindakan tersebut dilakukan. (Arikunto, 2013:138). Tindakan yang direncanakan adalah sebagai berikut :

1. Mengidentifikasi permasalahan yang dihadapai guru dan siswa dalam kegiatan pembelajaran pada observasi awal.

2. Merancang pembelajaran berdasarkan tema untuk pemecahan masalah dalam peningkatan kemampuan berhitung dengan menggunakan metode fingermathic pada anak usia 5-6 tahun.

3. Peneliti menetapkan waktu pelaksanaan dan membuat Rencana program Pembelajaran harian (RPPH) dan modul pembelajaran fingermathic

4. Menyusun dan menyiapkan lembar obsevasi dan alat pendokumentasian kegiatan pambelajaran.

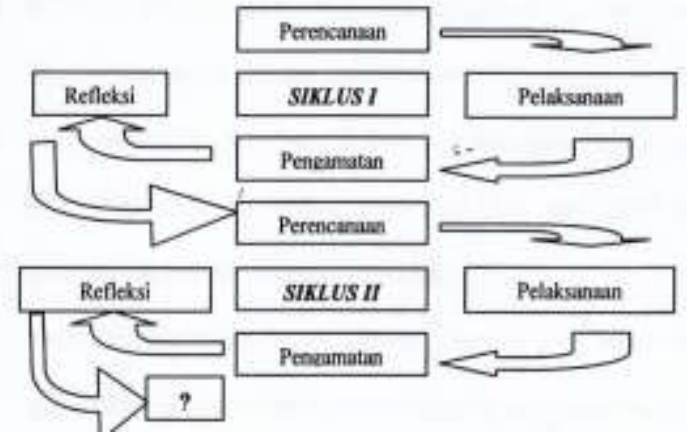

Gambar 1 Model Penelitian Tindakan Kelas Suharsimi Arikunto

b. Pelaksanaan Tindakan 
104 Jurnal PG-PAUD Trunojoyo : Jurnal Pendidikan dan Pembelajaran Anak Usia Dini, Volume 6, Nomor 2, Oktober 2019, hal 101 - 108, ISSN : 2528-3553 (online), ISSN: 2407-4454 (print)

Pelaksanaan ini dilakukan dengan menggunakan panduan dari perencanaan tindakan yang telah dibuat oleh peneliti dalam pelaksanaanya bersifat fleksibel terhadap perubahan-perubahan yang terjadi. Pada tahap ini peneliti berperan melakukan pengamatan jalannya proses pembelajaran dengan menggunakan lembar observasi yang telah dibuat. selain itu peneliti juga mengamati kegiatan pembelajaran dengan modul pembelajaran yang sesuai dengan penerapan metode fingermathic, adapun tindakan yang dilaksanakan adalah sebagai berikut :

1) Menyiapkan lembar observasi pelaksanaan pembelajaran.

2) Menyiapkan modul pembelajaran untuk meningkatkan kemampuan berhitung.

3) Setelah berbaris, anak-anak masuk kelas dan mengucapakan salam kemudian mengajak berdoa bersama.

4) Tahap penyampaian materi yang akan diajarkan, yaitu peneliti mengenalkan berhitung dengan menggunakan metode fingermathic.

5) Peneliti menyampaikan pengajaran dengan menggunakan metode fingermathic

6) Anak-anak berhitung dengan menggunakan metode fingermathic.

c. Observasi atau Pengamatan

Tahap obsevasi atau pengamatan dilakukan untuk mengumpulkan informasi tentang proses pembelajaran yang dilakukan guru sesuai dengan tindakan yang telah disusun (Sanjaya, Wina, 2011:79). Pengamatan pada penelitian ini dilaksanakan pada waktu proses pembelajaran sedang berlangsung. Dalam perencanaan pengamatan yang baik adalah pengamatan yang fleksibel dan terbuka untuk mencatat gejala yang muncul baik yang diharapkan maupun tidak diharapkan.

Pengamatan dilaksanakan dengan menggunakan lembar observasi yang telah dibuat. Penelitian dilakukan untuk melihat secara langsung bahwa metode fingermathic dapat meningkatkan kemampuan berhitung anak. Hasil dari proses pengamatan pembelajaran pada siklus I akan dijadikan masukan ketika peneliti melakukan refleksi untuk menyusun rencana ulang memasuki siklus selanjutnya.

d. Refleksi

Refleksi adalah kegiatan untuk mengemukakan kembali apa yang sudah terjadi (Arikunto,2013:140). Refleksi dilakukan untuk mengevaluasi kegiatan pembelajaran yang telah dilakukan dengan cara melakukan penilaian terhadap masalah yang muncul dan tindakan apa saja yang sudah dilakukan. Refleksi ini bertujuan untuk membuat kembali rencana tindakan yang baru untuk perbaikan pada siklus selanjutnya. Dari hasil refleksi ini, tindakan perbaikan akan ditentukan.

\section{Siklus II}

Tindakan yang dilakukan pada siklus II ini dilakukan setelah diperoleh hasil dari refleksi pada siklus I, karena hasil pada siklus I belum sesuai dengan indikator. Sebagai berikut langkah-langkah yang akan dilakukan pada siklus II :

a. Perencanaan

1) Mengidentifikasi permasalahan berdasarkan masalah pada refleksi siklus II

2) Menyiapkan Rencana Program Pembelajaran Harian (RPPH)

3) Menyiapkan lembar penilaian

4) menyiapkan lembar observasi

5) Menyiapkan modul jarimatika yang menggunakan metode fingermathic.

b. Pelaksanaan Tindakan

Pelaksanaan tindakan kedua dilakukan pada waktu pembelajaran berlangsung, yaitu :
1) Peneliti mengajak anak-anak membilang angkan dengan menggunakan metode fingermathic.

2) Peneliti dan siswa tanya jawab tentang perhitungan dengan menggunakan metode fingermathic.

3) Anak-anak mengerjakan modul fingermathic.

4) Peneliti dan anak-anak mengevaluasi bersama hasil kegiatan anak menghitung dengan menggunakan metode fingermathic.

c. Observasi atau Pengamatan

Observasi dilakukan untuk mengetahui peningkatan kemampuan berhitung dengan menggunakan metode fingermathic pada anak kelompok B TK 
Jurnal PG-PAUD Trunojoyo : Jurnal Pendidikan dan Pembelajaran Anak Usia Dini, Volume 6, Nomor 2, Oktober 2019, hal $101-108$, ISSN : 2528-3553 (online), ISSN: 2407-4454 (print)

Tunas Asri benowo Surabaya. Pengamatan yang dilakukan yaitu dari sebelum hingga sesudah diberikannya tindakan pada siklus II, peneliti mencatat semua hasil kegiatan yang dicapai anak dalam lembar observasi.

d. Refleksi

Dari data-data yang diperoleh dari observasi kemudian dicatat dan dikumpulkan serta dianalisis. Setelah semua idikator keberhasilan tercapai dengan maksimal peneliti bersepakat untuk menghentikan penelitian ini.

Dalam penelitian ini instrumen yang digunakan adalah bentuk check list. Wina Sanjaya (2009: 93) Check list merupakan daftar pedoman observasi yang akan digunakan oleh peneliti untuk mengamati aspek apa saja yang akan diobservasi, berisikan daftar aspek yang akan diobservasi, sehingga tugas sebagai observer tinggal memberi tanda $(\sqrt{ })$ pada bagian yang diobservasi.

Data yang didapat melalui observasi ini memberikan informasi tentang peningkatan kemampuan berhitung dengan menggunakan metode fingermathic. Indikator yang dipakai dalam penelitian ini adalah menyebutkan lambang bilangan, menyebutkan lambang bilangan dengan metode fingermathic, menghitung antara bilangan 1-20.

Teknik pengumpulan data yang digunakan pada penelitian ini yaitu observasi, dan dokumentasi. 1. Observasi. Observasi merupakan beberapa teknik yang dilaksanakan pada saat peneliti melaksana kan pengamatan secara teliti dan sistematis (Arikunto, 2010 :202). Pengumpulan data dalam observasi dilaksanakan sendiri oleh peneliti ditolong guru kelas dan kepala sekolah. Observasi dilakukan di kelas yang diambil subyek penelitian agar memperoleh gambaran secara langsung kegiatan belajar anak. Observasi ketika dilaksanakan pada proses belajar mengajar guru dan anak. Hal-hal yang di lakukan dalam observasi antara lain kemampuan anak dalam mengkoordinasi tangan dan keseimbangan tubuh terutama kaki sehingga mengoptimalkan ketrampilan Berhitunganak. 2. Dokumentasi. Dokumentasi adalah instrument dalam mengumpulkan data mengenai peristiwa masa lalu yang sudah di dokumentasikan (Mulyasa, 2009: 69). Dokumentasi ini adalah metode untuk mendapatkan sesuatu dengan buku-buku, arsip yang berhubungan dengan yang diteliti. Dokumentasi digunakan untuk memperoleh data sekolah dan nama anak kelompok B TK Tunas Asri Benowo Surabaya, serta foto rekaman proses tindakan penelitian.

Teknik analisis data dalam penelitian ini menggunakan analisis kuantitatif dan kualitatif. Data tersebut mulai dianalisis dari siklus I dan II untuk dibandingkan perolehan nilai rataratanya, hasil perhitungan dikonsultasikan dengan tabel kriteria deskriptif prosentase yang dikelompokkan dalam empat kategori belum berkembang, mulai berkembang, berkembang sesuai harapan, berkembang sangat baik.

Tabel 1. Kisi-Kisi Penilaian

\begin{tabular}{|c|c|c|c|}
\hline No & Indikator & Deskripsi & Skor \\
\hline \multirow[t]{4}{*}{1} & \multirow{4}{*}{$\begin{array}{l}\text { Anak } \\
\text { mampu } \\
\text { menyebutkan } \\
\text { lambang } \\
\text { bilangan }\end{array}$} & $\begin{array}{l}\text { Anak mampu } \\
\text { menyebutkan lambang } \\
\text { bilangan lebih dari 1-20 }\end{array}$ & 4 \\
\hline & & $\begin{array}{l}\text { Anak mampu } \\
\text { menyebutkan lambang } \\
\text { bilangan 1-20 dengan } \\
\text { berurutan }\end{array}$ & 3 \\
\hline & & $\begin{array}{l}\text { Anak mampu } \\
\text { menyebutkan lambang } \\
\text { bilangan 1-20 namun } \\
\text { belum berurutan }\end{array}$ & 2 \\
\hline & & $\begin{array}{l}\text { Anak mampu } \\
\text { menyebutkan lambang } \\
\text { bilangan } 1-20 \text { tetapi } \\
\text { dengan bantuan guru }\end{array}$ & 1 \\
\hline \multirow[t]{4}{*}{2} & \multirow{4}{*}{$\begin{array}{l}\text { Anak } \\
\text { mampu } \\
\text { menyebutkan } \\
\text { lambang } \\
\text { bilangan } \\
\text { dengan } \\
\text { metode } \\
\text { fingermathic }\end{array}$} & $\begin{array}{l}\text { Anak mampu } \\
\text { menyebutkan lambang } \\
\text { bilangan dengan metode } \\
\text { fingermathic lebih dari } \\
1-20\end{array}$ & 4 \\
\hline & & $\begin{array}{l}\text { Anak mampu } \\
\text { menyebutkan lambang } \\
\text { bilangan dengan metode } \\
\text { fingermathic 1-20 }\end{array}$ & 3 \\
\hline & & $\begin{array}{lr}\text { Anak } & \text { mampu } \\
\text { menyebutkan } & \text { lambang } \\
\text { bilangan dengan metode } \\
\text { fingermathic } \\
\text { dengan acak }\end{array}$ & 2 \\
\hline & & $\begin{array}{l}\text { Anak mampu } \\
\text { menyebutkan lambang } \\
\text { bilangan dengan metode } \\
\text { fingermathic } 1-20 \text { tetapi } \\
\text { dengan bantuan guru }\end{array}$ & 1 \\
\hline \multirow[t]{3}{*}{3} & \multirow{3}{*}{$\begin{array}{l}\text { Anak } \\
\text { mampu } \\
\text { berhitung } \\
\text { penjumlahan } \\
\text { dan } \\
\text { pengurangan } \\
1-20\end{array}$} & $\begin{array}{l}\text { Anak mampu berhitung } \\
\text { penjumlahan dan } \\
\text { pengurangan lebih dari } \\
1-20\end{array}$ & 4 \\
\hline & & $\begin{array}{l}\text { Anak mampu berhitung } \\
\text { penjumlahan dan } \\
\text { pengurangan } 1-20\end{array}$ & 3 \\
\hline & & Anak mampu berhitung & 2 \\
\hline
\end{tabular}


106 Jurnal PG-PAUD Trunojoyo : Jurnal Pendidikan dan Pembelajaran Anak Usia Dini, Volume 6, Nomor 2, Oktober 2019, hal 101 - 108, ISSN : 2528-3553 (online), ISSN: 2407-4454 (print)

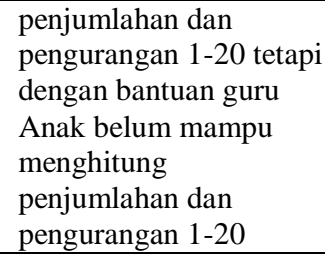

\section{Indikator Keberhasilan}

Penelitian Tindakan Kelas dinyatakan berhasil apabila anak dalam menyelesaikan tugas sedikitnya 3 dari 5 tugas itu benar sebanyak $75 \%$ dari jumlah anak, maka pemberian tugas itu dinyatakan berhasil. Tetapi apabila dampak dari tindakan belum mencapai kriteria tersebut, maka kegiatan penelitian akan diteruskan dengan memperbaikinya di siklus ke II berdasarkan refleksi proses dan hasil timdakan sebelumnya untuk meningkatkan presentasi pembelajaran anak sebagai hasil peningkatan kemampuan berhitung dengan menggunakan metode fingermathic pada anak kelompok B di TK. Tunas Asri Benowo Surabaya.

\section{HASIL DAN PEMBAHASAN}

Hasil

\section{Hasil Pra Siklus}

Hasil yang diperoleh dari kegiatan pra siklus ini yaitu rata-rata skor kemampuan berhitung pada kelompok B TK Tunas Asri Benowo Surabaya. Tabel 2.

\section{Hasil Observasi Kemampuan Berhitung} Anak Pra Siklus

\begin{tabular}{ccc}
\hline \multirow{2}{*}{ Kriteria } & \multicolumn{2}{c}{ Kondisi Awal } \\
\cline { 2 - 3 } & Jumlah Anak & Presentase (\%) \\
\hline BB & 9 & 69,23 \\
MB & 1 & 7,69 \\
BSH & 3 & 23,08 \\
BSB & 0 & 0 \\
\hline
\end{tabular}

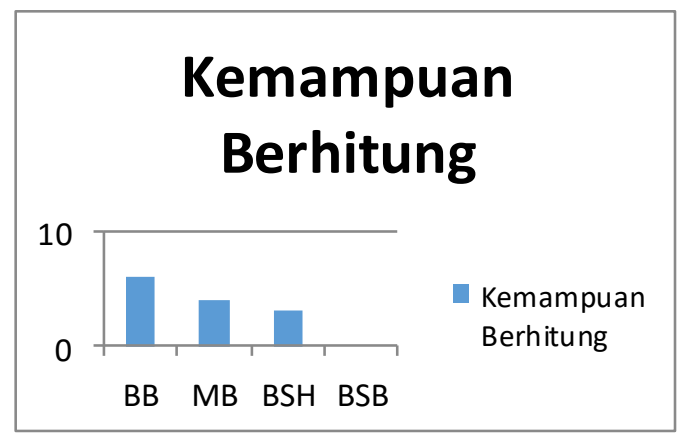

Gambar 2. Grafik Kemamapuan Berhitung pada Observasi Awal
Pada tabel 2 dapat dilihat kemampuan berhitung anak yang Belum Berkembang (BB) sebanyak 6 anak sekitar 46,15\%, Mulai Berkembang sebanyak 4 anak sekitar $30,77 \%$, dan Berkembang Sesuai Harapan (BSH) sebanyak 3 anak sekitar 23,08 \% saja.

Hasil observasi awal menunjukan bahwa kemampuan berhitung masih rendah belum dapat berkembang secara optimal, belum ada yang mencapai Berkembang sangat Baik (BSB) prosentasenya masih $0 \%$. Hal ini juga bisa dilihat pada grafik gambar 2 .

\section{Siklus I}

Hasil yang diperoleh dari kegiatan siklus I ini yaitu rata-rata skor kemampuan berhitung pada kelompok B TK Tunas Asri Benowo Surabaya.

Pada tabel diatas dapat dilihat kemampuan berhitung anak yang Belum Berkembang (BB) sebanyak 4 anak sekitar 30,77\%, Mulai Berkembang sebanyak sebanyak 1 anak sekitar 7,69\%, Berkembang Sesuai Harapan (BSH) sebanyak 7 anak sekitar 53,85\%, dan berkembang sangat baik 1 saja yaitu sekitar 7,69\% .

Tabel 3.

Hasil Observasi Kemampuan Berhitung Anak Siklus I

\begin{tabular}{ccc}
\hline \multirow{2}{*}{ Kriteria } & \multicolumn{2}{c}{ Kondisi Awal } \\
\cline { 2 - 3 } & Jumlah Anak & Presentase (\%) \\
\hline BB & 4 & 30,77 \\
MB & 1 & 7,69 \\
BSH & 7 & 53,85 \\
BSB & 1 & 7,69 \\
\hline
\end{tabular}

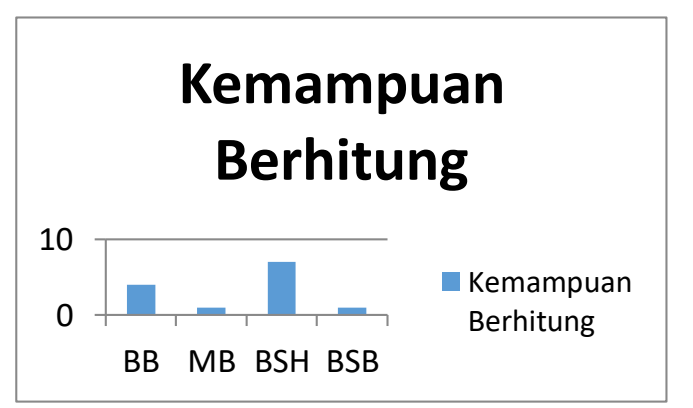

Gambar 3. Gambar Kemampuan Brehitung pada Siklus I 
Jurnal PG-PAUD Trunojoyo : Jurnal Pendidikan dan Pembelajaran Anak Usia Dini, Volume 6, Nomor 2, Oktober 2019, hal $101-108$, ISSN : 2528-3553 (online), ISSN: 2407-4454 (print)

Hasil observasi siklus I menunjukkan ada peningkatan dari pra siklus ke siklus I. Hal ini juga dapat dilihat pada grafik pada gambar 3 .

\section{Siklus II}

Hasil yang diperoleh dari kegiatan Siklus II ini yaitu rata-rata skor kemampuan berhitung pada kelompok B TK Tunas Asri Benowo Surabaya.

Pada tabel diatas dapat dilihat kemampuan berhitung anak yang Belum Berkembang (BB) hanya 1 anak sekitar 7,69\%, Mulai Berkembang juga hanya 1 anak sekitar 7,69\%, Berkembang Sesuai Harapan (BSH) sebanyak 3 anak sekitar $23,08 \%$ dan berkembang sangat baik 8 anak yaitu sekitar $61,54 \%$. Hal ini juga dapat dilihat pada grafik pada gambar 4 .

Setelah dilakukan tindakan kemampuan berhitung dengan menggunakan metode fingermathic pada siklus II dapat menunjukkan bahwa metode fingermathic mampu meningkatkan kemampuan berhitung anak. Hal tersebut dibuktikan dengan hasil prosentase kemampuan berhitung anak sudah mencapai $84,62 \%$ dikriteria Berkembang Sesuai harapan dan berkembang Sangat Baik.

Tabel 4.

Hasil Observasi Kemampuan Berhitung Anak Siklus II

\begin{tabular}{ccc}
\hline \multirow{2}{*}{ Kriteria } & \multicolumn{2}{c}{ Kondisi Awal } \\
\cline { 2 - 3 } & Jumlah Anak & Presentase (\%) \\
\hline BB & 1 & 7,69 \\
MB & 1 & 7,69 \\
BSH & 3 & 23,08 \\
BSB & 8 & 61,54 \\
\hline
\end{tabular}

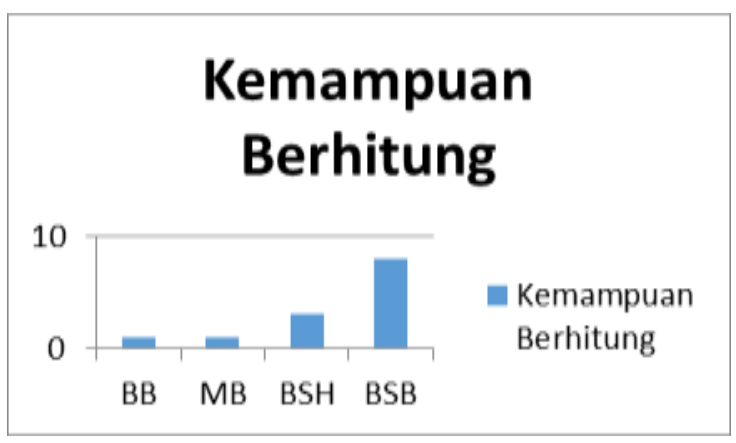

Gambar 4. Gambar Kemampuan Berhitung pada Siklus I
Berdasarkan hasil pelaksanaan diakhir siklus II, kemampuan berhitung dengan menggunakan metode fingermathic meningkat dengan baik, yang mana sudah memenuhi kriteria keberhasilan yang telah ditentukan oleh peneliti yaitu $75 \%$, maka siklus berakhir pada siklus II.

\section{SIMPULAN}

Berdasarkan dari hasil penelitian dan pembahasan mengenai penelitian tindakan kelas (PTK) pada peningkatan kemampuan berhitung dengan menggunakan metode fingermathic pada anak usia dini TK Tunas Asri Benowo Surabaya, dapat disimpulkan bahwa secara keseluruhan hasil observasi penelitian kali ini menunjukkan hasil yang sesuai dengan harapan,dimana terjadi peningkatan yang cukup signifikan dimulai dari hasil pra siklus pada presentase $23,08 \%$ kemudian meningkat menjadi $61,54 \%$ pada masa siklus 1 dan di tuntaskan pada siklus 2 yang mencapai keberhasilan memperoleh presentase sebesar $84,62 \%$.

\section{SARAN}

Dengan pembuktian bahwa dengan menggunakan metode fingermathic dapat meningkatkan kemampuan berhitung diantaranya adalah: (1). Dalam pembelajaran, diharapkan guru tidak hanya terpaku pada model yang umum dilakukan tetapi juga mempelajari dan mencoba mempraktekkan berbagai model, metode, maupun teknik pembelajaran yang beragam agar dapat memberikan kesan khusus bagi anak terutama untuk meningkatkan kemampuan membilang anak usia dini; (2). Dalam pembelajaran, guru perlu mempraktekkan ilmu yang memiliki berbagai metode didalamnya untuk dipilih sesuai dengan materi dan karakteristik peserta didik; dan (3). Guru dapat melaksanakan penelitian baru untuk meningkatkan kemampuan berhitung anak usia dini.

\section{DAFTAR PUSTAKA}

Arikunto, Suharsimi dkk. 2010. Penelitian Tindakan Kelas. Jakarta: Bumi Askara

Depdiknas.2003. Undang-undang RI No.20 tahun 2003.tentang sistem pendidikan nasional. 
108 Jurnal PG-PAUD Trunojoyo : Jurnal Pendidikan dan Pembelajaran Anak Usia Dini, Volume 6, Nomor 2, Oktober 2019, hal 101 - 108, ISSN : 2528-3553 (online), ISSN: 2407-4454 (print)

E. Mulyasa. 2009. Praktik Penelitian Tindakan Kelas. Bandung: Rosdakarya.

Kuraesin, Iis. (2013). Usia Pra Sekolah Melalui Kartu Angka di Taman Kanak-Kanak TK Ketilang Sukahurip Kecamatan Cihaurbeuti Kabupaten Ciamis.Universitas Terbuka. Tasikmalaya.

Piaget. 1992. Prinsip Belajar dan Pembelajaran. Jakarta. Departemen Pendidikan dan Kebudayaan.

Setiawan, Denny. 2007. Pengembangan Bahan Ajar. Jakarta: Universitas Terbuka

Slamet Suyanto. (2003). Konsep Dasar

Pendidikan Anak Usia Dini.

Yogyakarta: Universitas Negeri

Yogyakarta. 